\title{
Isolasi Bakteri Pengakumulasi Poliposfat
}

\section{Isolation of Polyphosphate Accumulating Bacteria}

\section{Made Sudiana}

Pusat Penelitian Biologi-LIPI, Jl. Juanda 18 Bogor 16122. Telp. (0251) 324006, Fax: 62-251-325854

E-mail : sudianai@yahoo.com

\begin{abstract}
Polyphosphate accumulating bacteria play important key role on biological phosphorous removal. Activated sludge originated from wastewater treatment plant for drinking water production acclimated with anaerobic-aerobic phase in sequential batch reactor continuously succeed to establish microbial community that are able to adsorb glucose and acetate under anaerobic condition. Acinetobacter calcoaceticus S1 was an isolated bacterium from community performing organic substrate absorption. $\mathrm{S} 1$ is able to adsorb glucose and acetate under anaerobic condition. During substrate absorption an increase of orthophosphate in bulk solution indicating phosphate released out of cell. Reduction of glycogen and polyhydroxybutirate (PHB) took place under anaerobic phase. $\mathrm{S} 1$ is a community member of anaerobic-aerobic system for removal of phosphorous in influent wastewater.
\end{abstract}

Key words: Polyphosphate accumulating bacteria, Acinetobacter, anaerobic-aerobic process

Diterima : 20 September 2003, disetujui: 2 Maret 2004

\section{Pendahuluan}

Proses anaerobik-aerobik (AA) merupakan proses yang umum digunakan untuk mengurangi kandungan bahan organik pada air limbah buangan (Kortstee et al., 1994). Akhir-akhir ini AA makin banyak diterapkan pada unit pengolahan limbah (UPL) domestik maupun limbah industri (Sudiana et al., 1998). Keunikan sistem AA adalah absorpsi substrat organik terjadi pada kondisi anaerobiknya (Mino, 1994), tidak seperti sistem UPL biasa yang menerapkan sistem lumpur aktif aerobik (A), sebagian besar absorpsi dan konversi senyawa organik terjadi pada lingkungan aerobik. Keuntungan sistem AA antara lain adalah biaya operasi yang lebih rendah dari sistem biasa yang menerapkan sistem aerobik. Hal tersebut disebabkan oleh limbah padat (endapan lumpur aktif) yang dihasilkan lebih sedikit. Potensi lain dari sistem AA adalah limbah padat yang dihasilkan mengandung fosfat yang lebih tinggi dibandingkan pada sistem aerobik (Fuhs and Chen, 1975). Kekurangan proses AA adalah kemampuannya dalam mengurangi beban senyawa organik dan nutrient fosfat tidak stabil (Kortstee et al., 1994). Hal tersebut disebabkan oleh masih kurangnya pemahaman metabolisme proses AA yang melibatkan komunitas mikroba yang mampu hidup pada kondisi anaerobik dan aerobik (Sudiana et al, 1999). Oleh karena itu perlu dipelajari karakter fisiologis dan metabolisme mikroba yang berperan pada proses AA terutama komunitas mikroba pengakumulasi posfat (MPF) (Mino, 1994). Mikroba tersebut diduga memiliki karakter metabolisme yang unik yaitu dapat melakukan absorpsi substrat pada kondisi anerobik. Sumber energi yang digunakan untuk absorpsi senyawa organik pada kondisi anaerobik pada mikroba aerobik adalah ATP yang digunakan untuk absorpsi substrat berasal dari proses fosforilasi oksidatif (Mino et al., 
1987). Seperti diketahui bahwa siklus Kreb hanya berfungsi sempurna pada kondisi aerobik, di mana siklus ini berakhir pada rantai respirasi dengan menggunakan oksigen sebagai elektron terminal (Mino, 1994). Dengan demikian pada organisme yang hidup pada kondisi anaerobik-aerobik, siklus Kreb tidak berfungsi (Satoh, 1992). Mino et al. (1987) menduga bahwa MPF mendapatkan energi dari hasil hidrolisis polifospat yang terdapat di dalam sel. MPF mengakumulasi polifospat melebihi mikroba yang umum terdapat pada UPL. Banyak teknik isolasi yang telah dikembangkan untuk mengisolasi mikroba yang mampu melakukan metabolisme seperti MPF, namun belum banyak yang berhasil. Tujuan penelitian ini adalah mendapatkan MPF yang mampu mengabsorpsi substrat pada kondisi anaerobik serta mempelajari ciri metabolisme dari mikroba tersebut.

\section{Metode Penelitian}

\section{Sumber lumpur aktif}

Lumpur aktif diambil dari UPL yang mengolah air untuk pembuatan air minum di Bandung yang menerapkan sistem anaerobikaerobik. Lumpur aktif yang diambil berasal dari tangki aerobik.

\section{Penyiapan anaerobik-aerobik SBR (sequential batch reactor)}

Anaerobik-aerobik SBR adalah sistem yang menerapkan kondisi anaerobik-aerobik pada satu tangki. Reaktor seperti ini mempunyai keuntungan mudah dioperasikan. Reaktor terbuat dari tabung polyethylene dengan total volume 2 liter, dan volume kerja 1,8 liter. Kondisi anerobik dibuat dengan mengalirkan gas $\mathrm{N}_{2}$ pada awal fase anaerobik kemudian reaktor ditutup untuk menghindari kontak dengan udara luar. Kondisi aerobik dibuat dengan mengalirkan udara kedalam reaktor dengan menggunakan pompa udara. Untuk mengatur kondisi substrat homogen, lumpur aktif diaduk dengan menggunakan stirer. Pada akhir masa aerobik, pengaduk dimatikan untuk memudahkan terjadinya pengendapan lumpur aktif. Sekitar $900 \mathrm{ml}$ supernatan pada akhir waktu pengendapan dibuang dan diganti dengan air yang baru. Kondisi operasi reaktor adalah fase anaerobik selama 3 jam, fase aerobik selama 9 jam dan sedimentasi selama 2 jam. Beban senyawa organik sekitar $0,5 \mathrm{~kg} \cdot \mathrm{m}^{-3}$. hari ${ }^{-1}$. Komposisi air limbah sintetik terdiri dari $66,2 \% \mathrm{CH}_{3} \mathrm{COONa}$,

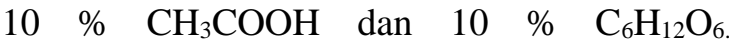
Alkalinitas yang terdiri dari $1,2 \% \mathrm{KH}_{2} \mathrm{PO}_{4}, 0,8$ $\mathrm{K}_{2} \mathrm{HPO}_{4}, 1,2 \% \mathrm{CaSO}_{4}$, dan 0,6 \% $\mathrm{MgSO}_{4}$, serta sumber $\mathrm{N}$ berupa pepton sebesar $10 \%$.

\section{Penentuan MLSS}

Filter dikeringkan selama 4 jam pada suhu $105^{\circ} \mathrm{C}$, disimpan dalam eksikator, dan ditimbang bobotnya. Sebanyak $15 \mathrm{ml}$ sampel disaring dengan menggunakan bantuan pompa hampa. Setelah itu filter dimasukkan ke dalam oven selama 4 jam pada suhu $105^{\circ} \mathrm{C}$, kemudian dihitung MLSS dengan mencari selisih antara berat kering filter sebelum dan setelah diberi lumpur aktif, dibagi dengan volume sampel (APHA, 1992).

\section{Monitoring aktivitas reaktor}

Aktivitas lumpur aktif dalam menurunkan posfat diikuti dengan mengukur kadar glukosa dengan metoda asam dinitrosalisilat (Miller, 1959) dan asam asetat dengan gas kromatograpi (Mino et al., 1998), yang dilakukan pada saat awal fase anaerobik, akhir fase anaerobik serta pada akhir fase aerobik.

\section{Isolasi MPF}

Pada saat komunitas MPF terbentuk, yang ditandai dengan digunakannya sebagian besar senyawa organik pada kondisi anaerobik, dilakukan isolasi mikroba. Sebanyak $5 \mathrm{ml}$ lumpur aktif diambil dari reaktor, kemudian dilakukan pengenceran bertingkat dengan menggunakan akuades steril, sampai pengenceran $10^{-6}$. Selanjutnya hasil pengenceran tersebut dituang ke dalam media steril yang mengandung: $4 \mathrm{~g} / 1 \mathrm{CH}_{3} \mathrm{COONa}, 1,5$ $\mathrm{ml} / 1 \mathrm{CH}_{3} \mathrm{COOH}$ dan $0,1 \mathrm{~g} \mathrm{C}_{6} \mathrm{H}_{12} \mathrm{O}_{6}$. Alkalinitas yang terdiri dari $0,44 \mathrm{~g} / \mathrm{l} \mathrm{KH}_{2} \mathrm{PO}_{4}, 0,22 \mathrm{~g} / \mathrm{l}$ $\mathrm{K}_{2} \mathrm{HPO}_{4}, 0,2 \mathrm{~g} / \mathrm{l} \mathrm{CaSO}$, dan $0,2 \mathrm{~g} / \mathrm{l} \mathrm{MgSO}_{4}, 2$ $\mathrm{g} / \mathrm{l}$ peptone, dan agar $18 \mathrm{~g} / \mathrm{l}$. Kultur ditumbuhkan pada inkubator suhu $28^{\circ} \mathrm{C}$ 
selama 3 hari. Kultur yang tumbuh selanjutnya dilakukan pengecatan Neisser dan Gram (Sudiana et al., 1998). Isolat yang positif terhadap pengecatan Neisser selanjutnya diuji karakteristik absorpsi senyawa organik dengan percobaan curah.

\section{Percobaan curah}

Percobaan curah dilakukan untuk mengetahui secara akurat dinamika senyawa organik dan posfat pada kondisi anaerobik-aerobik. Prosedur pengukuran mengikuti Sudiana et al. (1999). MLSS untuk percobaan absorpsi senyawa organik pada kondisi aerobik dan anaerobik diatur sekitar $2500 \mathrm{mg} / \mathrm{l}$. Umur biakan yang digunakan adalah 48 jam yang ditumbuhkan pada medium yang mengandung $4 \mathrm{~g} / \mathrm{C} \mathrm{CH}_{3} \mathrm{COONa}, 1,5 \mathrm{ml} / 1 \mathrm{CH}_{3} \mathrm{COOH}$ dan 0,1 $\mathrm{g} \mathrm{C}_{6} \mathrm{H}_{12} \mathrm{O}_{6}$. Alkalinitas yang terdiri dari $0,44 \mathrm{~g} / \mathrm{l}$ $\mathrm{KH}_{2} \mathrm{PO}_{4}, 0,22 \mathrm{~g} / 1 \quad \mathrm{~K}_{2} \mathrm{HPO}_{4}, 0,2 \mathrm{~g} / 1 \mathrm{CaSO}_{4}$, dan $0,2 \mathrm{~g} / 1 \mathrm{MgSO}_{4}, 2 \mathrm{~g} / \mathrm{l}$ peptone, dan agar $18 \mathrm{~g} / \mathrm{l}$. Kultur ditumbuhkan pada inkubator suhu $28^{\circ} \mathrm{C}$ selama 3 hari.

\section{Analisis PHB}

Sebanyak $10 \mathrm{ml}$ lumpur aktif disentrifugasi dengan kecepatan $5000 \mathrm{rpm}$ selama 10 menit, pelet yang terbentuk dicelupkan ke dalam air mendidih selama 5 menit, kemudian didinginkan pada temperatur kamar selama satu jam dan pada freezer selama 12 jam. Selanjutnya dipindahkan ke dalam freeze dryer selama 48 jam. Ke dalam tabung tersebut dimasukkan $2 \mathrm{ml}$ acidified methanol (10\% asam sulfat), yang mengandung asam benzoat sebagai internal standar, dan $2 \mathrm{ml}$ kloroform. Selanjutnya, tabung ditutup rapat, digojok, lalu dipanaskan dalam oven selama 20 jam pada suhu $105^{\circ} \mathrm{C}$, kemudian didinginkan pada suhu kamar. Langkah selanjutnya memasukkan ke dalam tabung $1 \mathrm{ml}$ larutan amonia 14\% melalui penutup lobang. Tabung digojok lagi, setelah itu disentrifugasi, bagian bawah dari kloroform dipindahkan ke tabung yang lain. Untuk memurnikan sampel, digunakan sebanyak $0,5 \mathrm{ml}$ air yang ditambahkan ke dalam sampel, lalu digojok dan disentrifugasi. Sebanyak $0,5 \mu l$ sampel kemudian dianalisis dengan kromatograpi gas (Hewlett Packard 5880A) dilengkapi dengan kolum DB-1 (internal diameter $0,32 \mathrm{~mm}$, ketebalan film $0,25 \mu \mathrm{m}$ dan panjang $30 \mathrm{~m}$ ), dan detektor yang digunakan adalah FID. Gas Helium $2 \mathrm{ml} / \mathrm{min}$ digunakan sebagai gas pembawa atau fase gerak dan suhu injektor ditetapkan $225^{\circ} \mathrm{C}$, suhu detektor adalah $280^{\circ} \mathrm{C}$, sedangkan suhu kolum pada saat awal injeksi $70^{\circ} \mathrm{C}$ selama 4 menit setelah injeksi, kemudian ditingkatkan dengan $8^{\circ} \mathrm{C}$ per menit, sampai mencapai suhu $118^{\circ} \mathrm{C}$. setelah itu suhu ditingkatkan lagi dengan $30^{\circ} \mathrm{C}$ per menit hingga mencapai suhu akhir $200^{\circ} \mathrm{C}$. Sebagai 3-HB digunakan 3-hydroxybutyrate dan sodium-2-hydroxyvalerate digunakan sebagai standard 3HV. PHA sampel yang dimurnikan dari lumpur aktif setelah diaklimasi dengan propionat pada kondisi anaerobik digunakan sebagai standard $3 \mathrm{H} 2 \mathrm{MV}$ setelah dideterminasi komposisinya dengan spektrometri NMR (Satoh et al., 1992).

\section{Hasil dan Pembahasan}

Komunitas MPF mulai terbentuk setelah satu minggu aklimasi yang ditandai oleh absorpsi substrat glukosa dan asetat sebagian besar terjadi pada kondisi anaerobik (Gambar 1 dan 2). Setelah 3 minggu aklimasi lebih dari 95\% susbtrat digunakan pada kondisi anaerobik. 


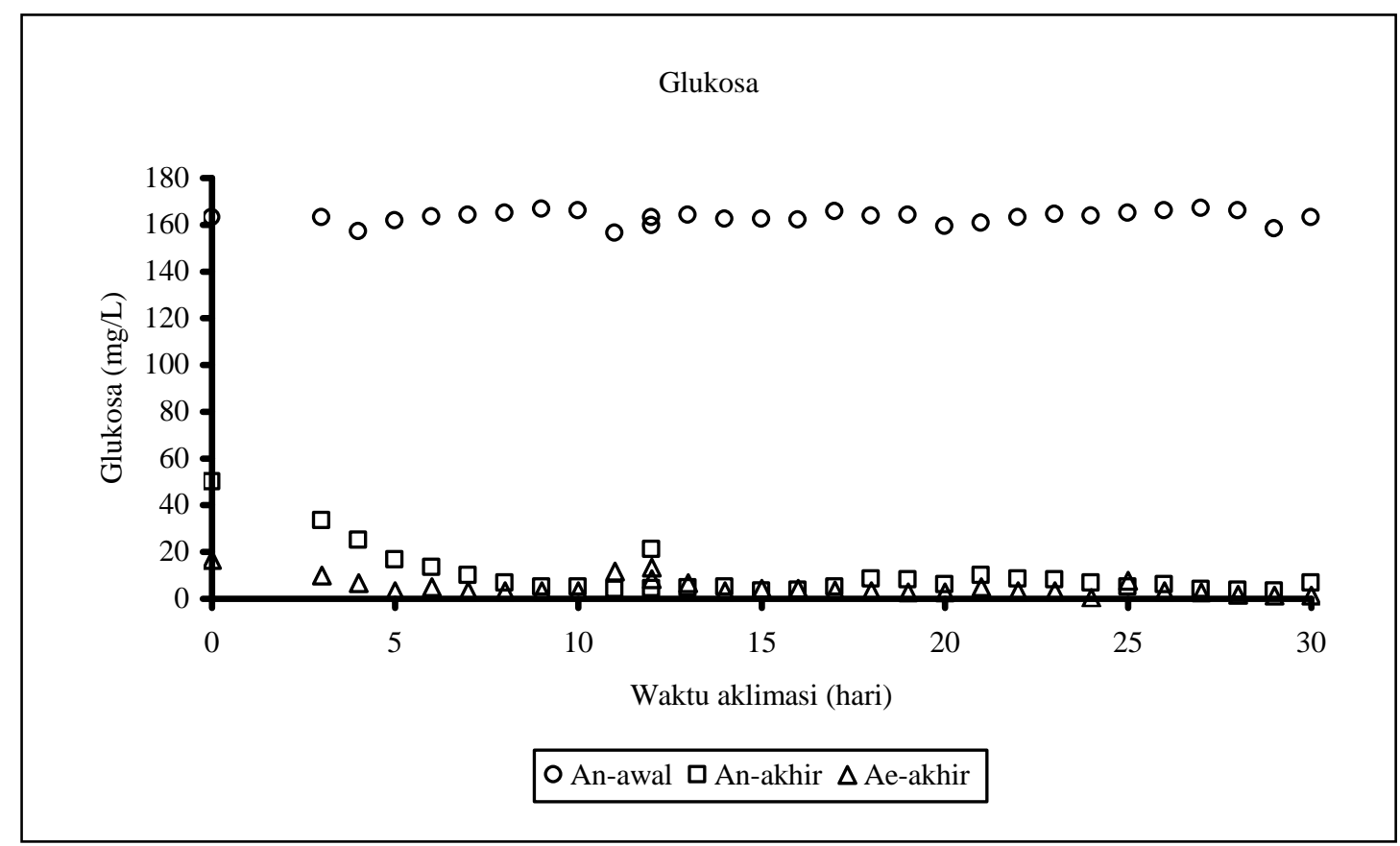

Gambar 1. Profil glukosa selama aklimasi

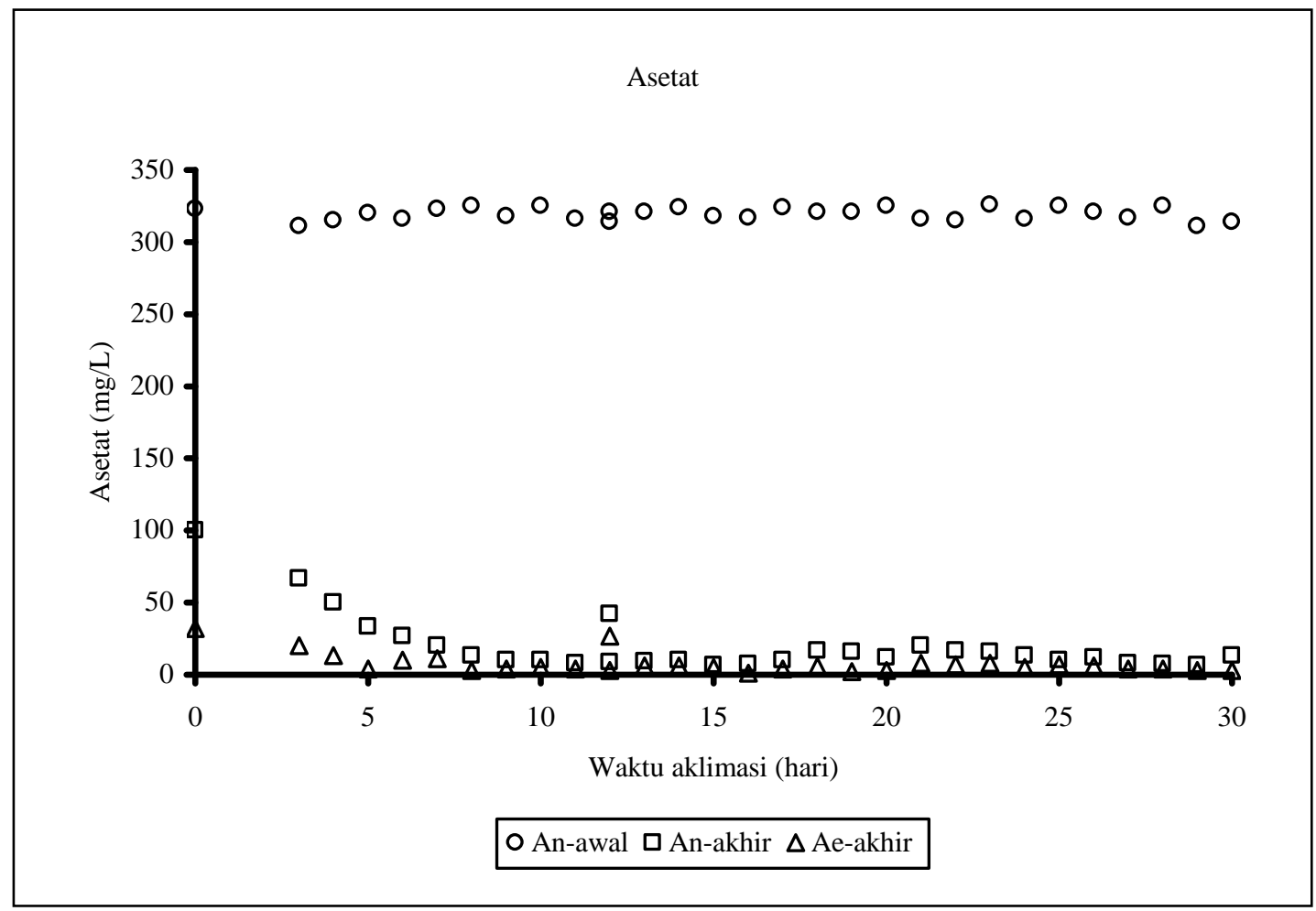

Gambar 2. Profil asetat selama aklimasi 
Hal tersebut disebabkan oleh rendahnya populasi MPF yang menyebabkan rendahnya absorpsi glukosa dan asetat pada awal aklimasi. Kemudian setelah komunitas MPF terbentuk, pelepasan fosfat pada kondisi anaerobik akan meningkat dengan cepat. Selanjutnya fosfat yang dilepaskan pada kondisi anerobik diserap oleh MPF pada kondisi aerobik (Gambar 3). Aktivitas absorpsi optimum pada saat komunitas MPF mendominasi, terjadi peningkatan biomassa lumpur aktif selama aklimasi (Gambar 4) yang disebabkan oleh peningkatan beban senyawa organik. Sebagian besar biomassa yang terbentuk merupakan komunitas MPF, seperti terjadi peningkatan absorpsi substrat pada kondisi anaerobik.

\section{Komunitas MPF.}

Dari 28 biakan yang berhasil diisolasi, hanya satu biakan yang positif terhadap Neisser dan dapat menggunakan asetat pada kondisi anaerobik. Biakan tersebut adalah S1 dengan ciri morfologis dan fisiologis; sel berbentuk batang, diameter 0,9-1,6 $\mu \mathrm{m}$, dan panjang sekitar 1,5-2,5 $\mu \mathrm{m}$, gram negatif, oksidase negatif, dan katalase positif serta mampu tumbuh dengan baik pada suhu $30-37^{\circ} \mathrm{C}$. Ciri fisiologis lainnya adalah: glutamil transferase + , tidak dapat menghidrolisis gelatin, tetapi dapat menggunakan sitrat, glutarat, DL-laktat, fenilasetat, malonat, L-Histidine, $\beta$-alanin, Ltyrosin, etanol, 2,3 butanediol, L-arginine, Lornitin, dan glutarat. Bakteri S1 juga dapat melakukan fermentasi glukosa menjadi asam. Secara keseluruhan, bakteri S1 mempunyai kemiripan morfologis dan fisiologis dengan Acinetobacter calcoaceticus (Holt et al., 1994). Selanjutnya untuk mengetahui kemampuan jasad renik tersebut sebagai MPF, dilakukan percobaan curah.

\section{Percobaan curah}

Ciri metabolisme bakteri Acinetobacter calcoaceticus S1 mirip dengan metabolisme komunitas mikroba lumpur aktif yaitu mampu tumbuh cepat pada sistem anaerobik-aerobik, menggunakan glukosa dan asetat sebagai sumber karbon utama pada kondisi anaerobik (Gambar 3), dan mampu mengakumulasi fosfat. Absorpsi yang optimum terjadi pada awal waktu inkubasi.

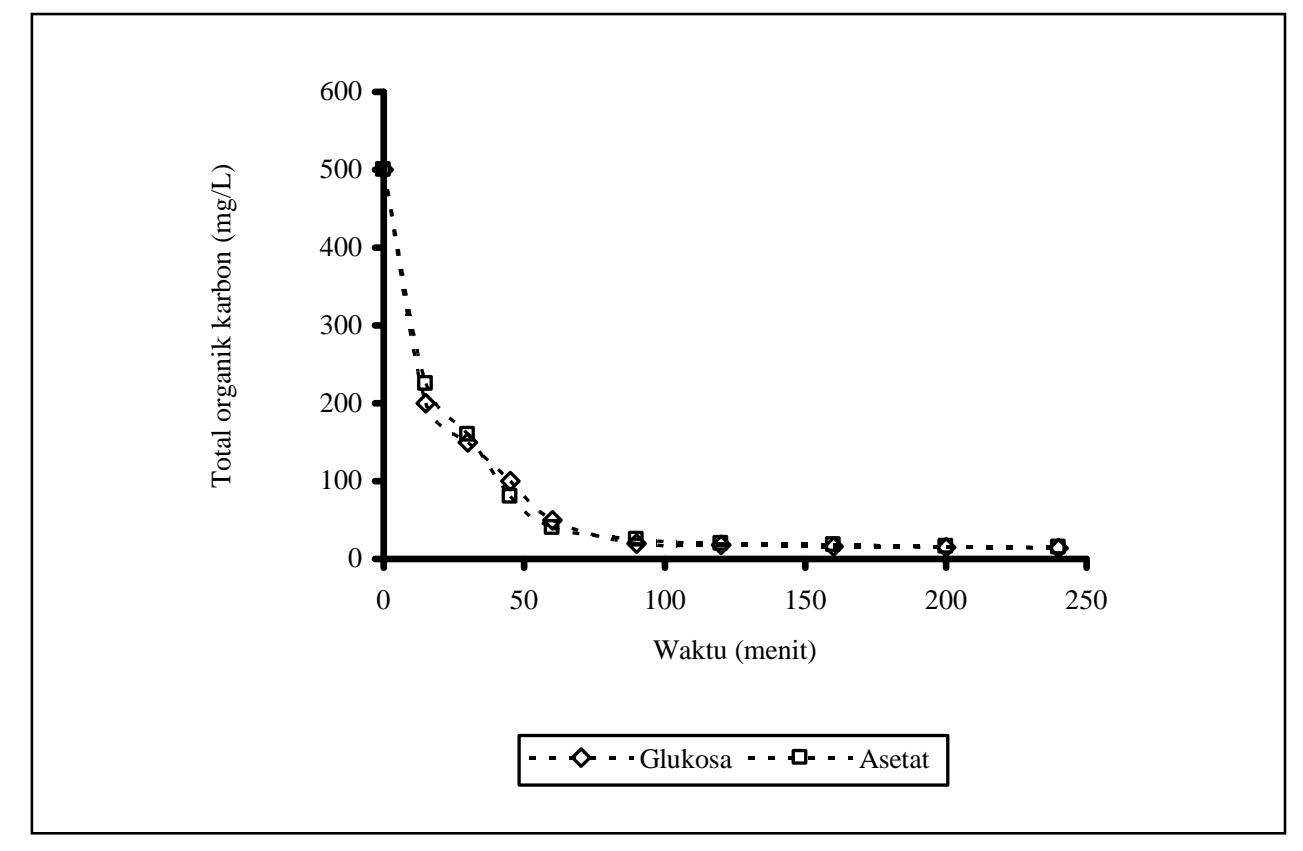

Gambar 3. Profil absorpsi substrat glukosa dan asetat 
Hampir 90\% glukosa yang ditambahkan diserap pada awal waktu aklimasi yang menunjukkan bahwa glukosa merupakan salah satu sumber karbon yang paling mudah digunakan oleh komunitas bakteri UPL yang menerapkan sistem anaerobik-aerobik (Satoh et al., 1992; Sudiana et al., 1998). Kemampuan absorpsi substrat oleh S1 ditentukan oleh banyak faktor antara lain banyaknya granula polifospat yang terdapat di dalam sel, pH, keberadaan mineral seperti $\mathrm{Ca}^{2+}$, $\mathrm{Mg}^{2+}$ dan $\mathrm{K}^{+}$(Mino et al., 1994; Sudiana et al., 1998), serta kemampuan akumulasi PHB (Gambar 4) (Satoh et al., 1992; McCool et al., 1996).

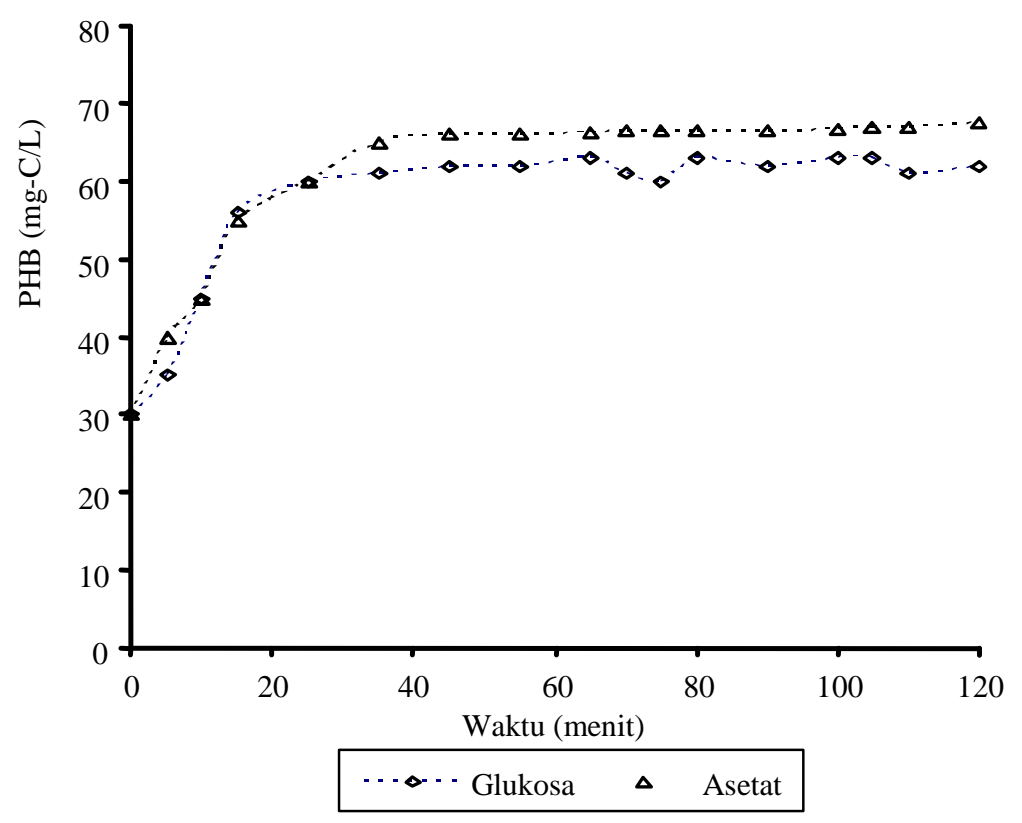

Gambar 4. Profil PHB

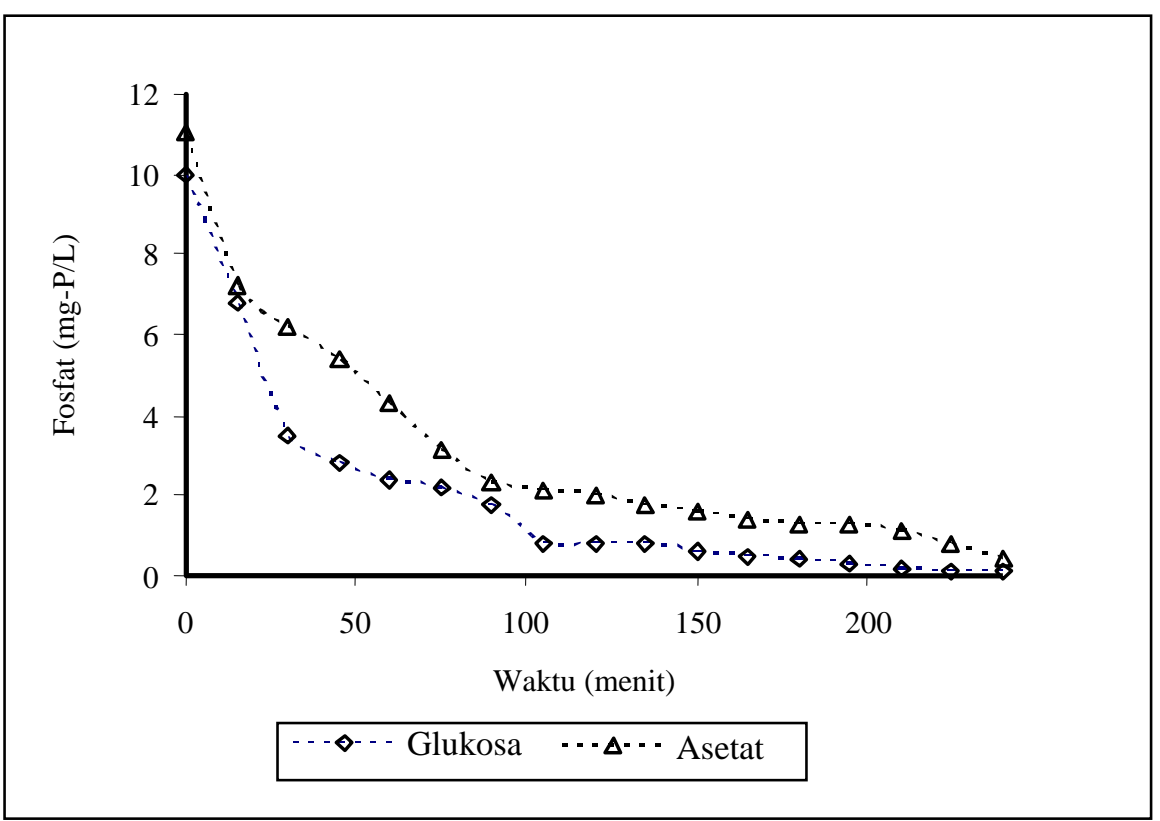

Gambar 5. Profil posfat pada kondisi aerobik 
Kedua sumber karbon utama (asetat dan glukosa) tersebut dapat dengan mudah digunakan oleh komunitas Acinetobacter calcoaceticus S1 (Gambar 3). Selanjutnya senyawa organik yang terserap ke dalam sel pada kondisi anaerobik dikonversi menjadi PHB (Gambar 4). Kemampuan S1 memproduksi $\mathrm{PHB}$, dan menggunakan asetat dan glukosa pada kondisi anaerobik, serta hidrolisis polifosfat menunjukkan peran biakan tersebut sebagai MPF (Sudiana et al., 1999). Pada saat terjadi absorpsi substrat, terjadi pula pelepasan orthoposfat yang menunjukkan bahwa energi yang digunakan untuk menyerap senyawa organik berasal dari hidrolisis polifospat (Mino et al., 1998).

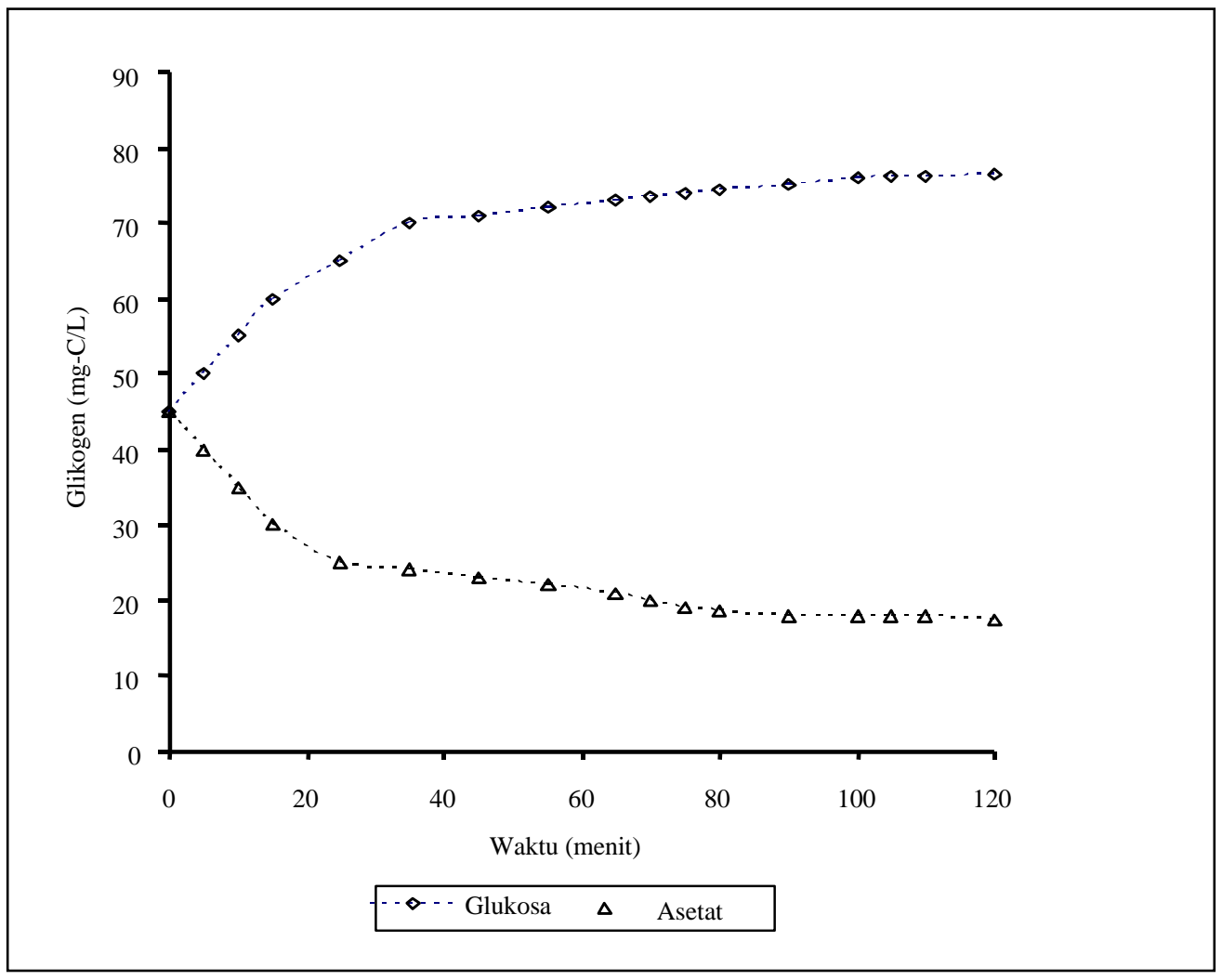

Gambar 6. Profile glikogen pada percobaan curah

Pada kondisi aerobik terjadi penyerapan orthoposfat yang menyebabkan penurunan fosfat di luar sel (Gambar 5). Keberhasilan sistem anaerobik-aerobik dalam menstimulasi terbentuknya mikroba MPF ditentukan oleh banyak faktor diantaranya keberadaan senyawa organik rantai pendek, seperti asam asetat, propionat, laktat dan senyawa hasil fermentasi, frekuensi siklus anaerobik-aerobik dan kandungan nitrat di dalam air limbah (Comeau et al., 1986). Indikasi dini dari kerberhasilan proses tersebut adalah kecepatan absorpsi substrat organik pada kondisi anaerobik (Sudiana et al., 1998). Akan tetapi ada dua komunitas mikroba yang mampu menggunakan senyawa organik pada kondisi anaerobik di dalam UPL yaitu mikroba MPF dan mikroba pengakumulasi glikogen (Liu et al., 1996). Kedua kelompok mikroba tersebut berkompetisi dalam mendapatkan substrat.

Profil glikogen pada absorpsi substrat asetat dan glukosa berbeda. Jika asetat digunakan sebagai sumber karbon utama maka metabolisme mengarah kepada sintesa PHA dan reduksi glikogen (Gambar 6). Akan tetapi pada saat glukosa digunakan, maka anabolisme mengarah ke sintesa glikogen. Hal tersebut menunjukkan bahwa pada saat sintesa PHB 
dari asetat diperlukan senyawa pereduksi dalam bentuk NADH. Senyawa tersebut dihasilkan melalui proses glikolisis (Mino et al., 1994).

Pada sistem anaerobik-aerobik yang diterapkan di Indonesia juga ditemukan komunitas MPF, hal ini terbukti setelah lumpur aktif diaklimasi lebih dari satu minggu terjadi penyerapan senyawa organik yang efektif. Meningkatnya pelepasan ortofosfat pada kondisi anaerobik pada saat penambahan beban senyawa organik menjelaskan adanya hubungan antara jumlah senyawa organik yang dapat diserap oleh MPF dengan konsentrasi polifospat yang terakumulasi di dalam sel. Kemampuan sel mengakumulasi fosfat dipengaruhi oleh mineral $\mathrm{K}, \mathrm{Ca}$ dan $\mathrm{Mg}$ dalam bentuk ion. Diketahui pula dalam pembentukan struktur molekul polifospat diperlukan rangka $\mathrm{Ca}, \mathrm{M}$, dan $\mathrm{K}$ sebagai penyambung ikatan fosfat dan oksigen (Mino et al., 1987). Metabolisme MPF dalam penyerapan senyawa organik belum diketahui secara pasti. Analisis metabolisme penyerapan senyawa organik oleh S1 dalam sistem anaerobik-aerobik memperlihatkan meningkatnya kandungan polihidroksi alkanoat (PHA) pada fase anaerobik. Hal tersebut disebabkan oleh konversi senyawa organik seperti glukosa dan asetat di dalam sel menjadi PHA karena pada sintesis PHA diperlukan donor elektron dan energi dalam bentuk NADH dan ATP. Metabolisme biakan S1 yang menarik adalah absorpsi asetat pada saat anaerobik akan menyebabkan penurunan glikogen di dalam sel. Satoh et al. (1992) mengungkapkan bahwa kemungkinan hidrolisis glikogen menjadi asam piruvat akan menghasilkan dua molekul ATP dan dua molekul NADH yang selanjutnya akan digunakan oleh sel untuk memproduksi satu mol PHA. Metabolisme hidrolisis glikogen dan sistesa PHA merupakan keunikan metabolisme sel mempertahankan nilai status reaksi oksidasi dan reduksi seimbang di dalam sel (Mino et al., 1994). Untuk mengontrol penambatan fosfat di dalam air limbah lebih efektif maka diperlukan pengetahuan metabolisme MPF yang lebih rinci terutama bagaimana kontrol sintesis PHA dan hidrolisis glikogen.

\section{Kesimpulan}

Aklimasi lumpur aktif pada kondisi anaerobik-aerobik dengan substrat glukosa dan asetat dapat membentuk komunitas MPF. Isolasi dari komunitas tersebut dihasilkan bakteri Gram negatif, Neisser positif, mampu menggunakan substrat glukosa dan asetat pada kondisi anaerobik. Bakteri tersebut mempunyai morfologi dan fisiologi mirip dengan Acinetobacter calcoaceticus. Pembentukan komunitas bakteri Acinetobacter calcoaceticus S1 pada UPL dapat meningkatkan kualitas air limbah buangan.

\section{Ucapan Terimakasih}

Penulis mengucapkan banyak terimakasih kepada Dr. Hiroyasu Satoh dari Tokyo University, Jepang yang telah memberikan informasi tentang detil analisis PHB.

\section{Daftar Pustaka}

APHA. 1992. Standard Methods for The Examination of Water and Wastewater, $18^{\text {th }}$ Ed., American Public Health Association, Washington D.C.

Comeau, Y., Hall, K. J., Hancock, R.E.W and Oldham, W. K., 1986. Biochemical Model for Enhanced Biological Phosphorus Removal, Water Research, Vol 20 (12): 1511-1521

Fuhs, G.W. and Chen. M.C., 1975. Microbiological Basic of Phosphate Removal in Activated Sludge Process for the Treatment of Wastewater, Microb. Ecol.: 119- 138

Holt, J.G,. Krieg, N.R., Sneath, P.H.A, Staley, J.T. and Williams, S.T., 1994. Bergeys Manual of Determinative Bacteriology, $9^{\text {th }}$ Ed., Lipincot Williams \& Wilkins. Tokyo.

Kortstee, G. J. J., Appledoorn, K. J., Bonting, C. F. C., van Niel, E. W. J. and van Veen. H. W., 1994. Biology of Polyp - Accumulating Bacteria Involved in Enhanced Biological Phosphorus Removal, FEMS Microbiol., Rev. 15: 137-153 
Liu , W., Mino, T., Nakamura, K. and Matsuo, T., 1996. Glycogen Accumumating populations and its anaerobic substrate uptake in anaerobic-aerobic sludge without biological phosphorous removal. Wat Res. 30: 75-82

McCool G.J., Feranadez, T. Li. N. and Cannon, M.C., 1996. Polyhydroxyalkanoat inclusion body growth and poliferation in Bacillus megaterium. FEMS Microbiology Letters $138: 41-48$.

Miller, G.L., 1959. Use of Dinitrosalicylic Acid Reagent for Determination of Reducing Sugar. Anal. Chem. 31: 426-428.

Mino, T., Arun, V., Tsuzuki, Y., Matsuo, T., 1987. Effect of Phosphorus Accumulation on Acetate Metabolism in Biological Phosphorus Removal Process, Wat. Sci. Tech., 23: 567- 576

Mino, T., 1994. Biological Phosphorus Removal Technology, Contemporary Studies in Urban Planning and Environmental Management in Japan, Dept. of Urban Engineering The University of Tokyo, Kajima Institute Publ., Tokyo.

Mino, T., Satoh, H, and Matsuo, T., 1995. Metabolism of Different Bacterial Populations in Enhanced Biological Phosphate Removal Processes. Wat. Sci. Tech. Vol 29, (7): 67-70.
Satoh, H., Mino, T. and Matsuo.T. ,1992. Uptake of Organic Substrate and Accumulation of Polyhydroxyalkanoate Granule in Acinetobacter spp, Isolated from Activated Sludge, FEMS Microbiol. Lett., Vol. 94: 171-174

Sudiana. I.M., Mino. T., Satoh. H, and Matsuo T.,. 1998. Morphology, In-situ Identification with rRNA Targetted Probe and Respiratory Quinone Profile of Enhanced Biological Phosphorous Removal Sludge. Wat. Sci. Tech. No. 8-9: 69-76.

Sudiana. I.M., 1998. Metabolic Characteristic and Morphology of Glycogen Accumulating Organism in Enhanced Biological phosphorous Removal Sludge. Prosiding. Temu Ilmiah VII. Hiroshima, 5-6 September: 180-184.

Sudiana. I.M., Mino. T., Satoh. H., Nakamura. K., and Matsuo T., 1999. Metabolism of Enhanced Biological Phosphorous Removal and Non-Enhanced Biological Phosphorous Removal Sludge With Acetate and Glucose as Carbon Sources. Wat. Sci Tech. Vol 39: 29-35. 